\title{
Animated Video Influence on Disaster Preparedness Activity of SDN 01 Students, Cigondang, Pandeglang
}

\author{
${ }^{1}$ DADAN ISKANDAR, ${ }^{2}$ SURAYA MANSUR, \\ ${ }^{3}$ RAJAB RITONGA, ${ }^{4}$ NOVITA DAMAYANTI \\ 1,2 Universitas Mercu Buana, Jl. Meruya Selatan No. 1 Jakarta Barat. (021) 5840816, Indonesia \\ ${ }_{3,4}$ universitas Moestopo Beragama, Jl. Hang Lekir I 8, Tanah Abang, Jakarta, Indonesia \\ correspondence: dadan.iskandar@mercubuana.ac.id
}

\begin{abstract}
One of the relevant media to develop the preparedness of the students in facing disasters is animation video since it can impress its viewers, especially children. This study aims to examine the disaster preparedness activity of the students of SDN 01 Cigondang, Pandeglang, Banten through the influence of animation video. This study employed Stimulus-Organism-Response Theory and experiment method quantitative approach with a positivist paradigm. Samples of this research are 114 students of grade IV, $V$, and VI divided into two groups: group A consists of 58 students and group B consists of 57 students. Group A is the treatment group, treated by "tsunami aware" animation video;, and group B is the control group, treated by "tsunami aware" pictorial story media. The design used is Pretest-Posttest Control Group Design. This study analyzes data through descriptive and inferential statistics. The result shows that an animation video does influence the disaster preparedness of the students of SDN 01 Cigondang, Pandeglang.
\end{abstract}

Keywords: disaster preparedness, animation video, elementary school student

\section{Introduction}

Indonesia is one of the countries included in the Pacific Ring of Fire. Ring of Fire is a term for major areas in the basin of the Pacific Ocean where volcanic eruption occurs (Bronto, 2006).

Indonesia is a meeting point of three main plates: Eurasia, Indo-Australia, and Pacific. As a country located in the ring of fire, Indonesia has many active and inactive volcanoes. Indonesia has around 129 active volcanoes, which is around $17 \%$ of the volcanoes in the whole world (Pratomo Indyo, 2006).

One of the active volcanoes in Indonesia is Anak Krakatoa (Child of Krakatoa) Volcano. It is in the Sunda Strait and a meeting point between India-Australian plate and Eurasian plate. Anak Krakatoa is a volcano appeared firstly in 1927 after the explosion of Mount Krakatoa in 1883. The explosion is one of the most dangerous disasters recorded in the history. The mount exploded and released volcanic material with the volume exceeded 18 kilometers cubic which led to tsunami with larger wave and hot cloud waves.

Several months before the tsunami, the volcanic activity of Anak Krakatoa was increased, as recorded on $22^{\text {nd }}$ December 2018 at 7 AM, where BMKG (the Meteorology, Climatology and Geophysics Agency) released an early warning of the potential high waves surrounds the Sunda Strait. Eruption and weather of Sunda Strait triggered the high waves. The eruption has caused an enormous tsunami wave with a height of 30 to 40 meters and crashed along Banten west coast and Lampung south coast. The wave was formed in just a minute after the mount exploded and it happened for the next 15 minutes.

One of the affected areas was Cigondang Village, Labuan District, Pandeglang, Banten. The wave killed one person and another one was still missing. In addition, 200

Received: 2020-03-02, Revised: 2020-05-06, Accepted: 2020-06-07 
houses and 10 boats were damaged. The victims were mostly children, teenagers, and adults who lived by the coast. The impact of Banten Tsunami on December 22,2018 , is still felt by the fisheries sector in Pandeglang which experienced a drastic decline of 50 thousand tons from 200 tons (2018) to 150 tons (2019). "There is still a lot of fish. But because the fishing gear is lacking due to the tsunami, so it is indeed a bit down," said Head of Fisheries Service of Pandeglang Regency, Suaedi Kurdiatna, when confirmed by suarabanten.id on Wednesday (1/23/2020)(Saepulloh, 2020, https:// banten.suara.com/read/2020/01/22/162945/ imbas-tsunami-banten-produksi-ikan-dipandeglang-menurun-50-ribu-ton).

A few weeks later, Kompas.com reported an earthquake measuring 4.9 magnitudes shook the Lebak region, Banten, on Monday (02/17/2020), around 19.11 WIB. The earthquake had no tsunami potential. "The impact of the earthquake based on community reports in the form of shocks was felt in the Cikotok region, the Penyauangan Temple, Bayah, Malingping, Rangkasbelitung, Ciptagelar, Cilograng, Pandeglang, Banjarsari and Sukabumi with an intensity scale of III MMI," said the Head of Central Office of BMKG Region II Tangerang, Hendro Nugroho, through an official statement to Kompas.com (Dewi \& Hardiyanto, 2020, https://www.kompas.com/ tren/read/2020/02/17/203053665/terasahingga-sukabumi-gempa-m-49-di-lebakbanten-tak-berpotensi-tsunami?page=1).

Among the community, children are the most potential and essential generation to receive an understanding and knowledge on preventing and dealing with disasters as they are expected to be able to save themselves. Thus, education and preparedness are essentially needed before the disaster happens. It was reported that most of the victims were children, meaning that their ability to save themselves and also their experience in dealing with disasters have not trained yet. If children do not have the ability and knowledge to save themselves from disasters, they will experience a traumatic feeling that will affect their psychological states.

LIPI and UNESCO, in 2006, conducted research in three areas: Aceh Besar Regency, Bengkulu, and Padang. The research was aimed to examine the disaster preparedness level at school, household, and community by seeing through five parameters (knowledge, policy and guidance, emergency preparedness plan, warning system, and resource mobilization). It was found that the preparedness level at school is lower compared to the level at the community and the government.

Studies on disaster preparedness at school have been conducted by many scholars. There are studies on how the disaster preparedness affects students' behavior and knowledge (Daud, Sari, Milfayetty, \& Dirhamsyah, 2014), the role of communication (Sitorus, 2009), school capacity reinforcement toward disaster preparedness in Aceh (Oktari, Kumala, Rachmalia, \& Husna, 2015), the preparedness of the coastal communities (Ruli As'ari, 2006), (I Gusti Agung Haryawan, Ni Luh Gede Aris Maytadewi Negara, 2012), individual and household's preparedness (Damayanti, 2015), preparedness of urban society (Arif, 2018), study in Padang (Alhadi \& Sasmita, 2014) and (Ismayani, 2019), study by UNESCO in Nias (MPBI _ UNESCO, 2013), study in Bali (I Gusti Agung Haryawan, Ni Luh Gede Aris Maytadewi Negara, 2012), and the factors of disaster preparedness (Pratama, 2016).

The government has established The National Disaster Management Authority (/BNPB) responsible for national disaster prevention (Article 10 Law No. 24/2007). The National Disaster Management Authority (BNPB) Regulation concerning Organization and Work Ethics of BNPB in 2008 Article 1 mentioned that BNPB is responsible for guiding disasters prevention, emergency preparedness, rehabilitation, and fair reconstruction. One form of guidance carried out by BNPN is a tsunami animated video which was published on February 14, 2017 (https://youtu.be/V1eR6KG68Lo). From the perceptive of Stimulus-Organism-Response (SOR) theory, it is hoped that the video message (stimulus) will influence the disaster preparedness (response).

The Internet, since the early millennial era, has become a new media in providing information for most people in the world. The rising of new media is triggered by the power of communication technology that supports news spreading, equipped with high speed, accessibility, and more adaptive to its users. Sometimes new media depends on communication technology and it is also perceived negatively by society. This is reasonable if the existence of new media such as websites, Facebook, Instagram, Youtube, twitter, online games, and other online media are merely the complements to lifestyle, and are not used to increase public's insight. 
However, despite there are detrimental implications for the community, new media has played a role in supporting the efforts to find, obtain and use factual information, and create changes.

Youtube has appeared and succeeded as the most-used information media. It offers various sources of information that are more diverse than the television. In addition, Youtube has a stronger penetration power to be present at every moment of people's lives. This is supported by the ability of Youtube which can be accessed through a variety of devices other than computers, such as tablets, mobile phones, and even television (smart TV). These four things indicate that the frequency network has been defeated by the internet network to become the most consumed media information by the public. There is a correlation between media type, media content, media exposure and social context in watching Youtube with the fulfillment of information needs (Ahmadi, D, et.al., 2020).

The observation result shows that all students have their own gadgets and internet access. However, the students mostly use them for playing video games. Through the analysis, it is found that the lack of socialization on disasters preparedness has caused the students to have no comprehensive knowledge of disaster preparedness. The school only held tsunami simulation training once in 2016 collaborated with BNPB.

One of the relevant media in developing the need to possess the preparedness is animation video. As it contains moving pictures and sounds, an animation video is categorized as audiovisual. It can provide a more meaningful learning experience and stimulate more compared to reading activity since audiovisual and moving pictures are more impressive to the audience, especially children.

The reasons above have led to the realization of the importance of socialization in preparedness. The socialization is conducted by BNPB through an animation video. The target of the socialization is the people who live in disaster-prone areas. Based on the background of the problem, this study will examine how far the video animation has influenced the disaster preparedness of the students of SDN 01 Cigondang?

SOR theory is employed in this study. The point will be emphasized in this model is how the message could be easily internalized by the audiences to later change their behavior. Deddy Mulyana (Mulyana, 2007) explained that the most essential element in the SOR model are: Message (Stimulus, S), Communicant (Organism, O), and Effect (Response, R). Furthermore, attention, understanding, and acceptance of the 'siaga tsunami' (get ready for or tsunami warning) animation videos and pictorial stories should be considered whether they fulfill the three elements (SOR) or not. The videos are also published on Youtube. Some of the videos aforementioned are Youtube as a Learning Media at School (Everhart, 2009), Youtube on Preschool Kids (Davidson, Given, Danby, \& Thorpe, 2014), Kids YouTubers (McRoberts, Bonsignore, Peyton, \& Yarosh, 2016), Positive and Negative Effect of Youtube (O'Keeffe et al., 2011), Youtube Literacy Media (Kholisoh, 2018) (Meek, 2012), Learning Tool for Parents (Burroughs, 2017) (Hourcade, Mascher, Wu, \& Pantoja, 2015), and Advertisement and Learning for Children (Tan, Ng, Omar, \& Karupaiah, 2018) (Araújo et al., 2017).

The animation video is the result of hand-drawing processing. During its creation process, motion and shape transition effect are applied (Johnson, 2019). It could be said that animation is a well-arranged moving text and graphics in order to explain a certain concept in a more simple way.

Disaster preparedness on children aged 9-12 years old is definitely different from the adults. The children will absorb the knowledge better if it is presented in a more fun way, for instance, by using audiovisual or animation video. The researcher used animation media as it could give knowledge to the students who live in a disaster-prone area on how to be more prepared in dealing with a tsunami. "Siaga Tsunami" is an animation media tells about the definition of a tsunami, its causes, signs, how to get information and rescue, and also the effort to reduce the risk.

The video was published by BNPB in 2017 and aimed to give children knowledge about how tsunami occurs, its causes and effects, and the action to reduce its risk. The plot illustrates the knowledge to prevent tsunami and reduce the risks.

According to KBBI, disaster is a phenomenon that causes or creates distress, loss, and suffering. Meanwhile, Law No. 24 2007 explains that a disaster is an event or series of events that endangers the life of a certain community, caused both by nature or 
human and it causes fatalities, environmental damage, loss, and psychological effect. Disaster becomes a full package of three elements of threat, vulnerability, and ability triggered by an event (Pemerintah Republik Indonesia, 2007). Tsunami preparedness is needed to determine an action in facing disaster. As explained in Law No. 24 in 2007, disaster preparedness is a series of activities aimed to anticipate disaster through organizing effectively and efficiently.

The preparedness level of a community can decrease with the change in socioculture, politics, and economic conditions. Thus, preparedness should be monitored and improved (Valency \& Lazarte, 2007).

There are five parameters to assess preparedness (Valency \& Lazarte, 2007): (1) Knowledge and Attitude: knowledge on disaster risk. The knowledge possessed could influence people's attitudes and concerns, especially those who live in coastal areas that are vulnerable to natural disasters; (2) Policies regarding preparedness to anticipate natural disasters; (3) Emergency Response Plan: The plan becomes an essential part of preparedness, especially regarding evacuation and rescuing, thus, the victim number could be minimized. Hence, training and simulation are needed about what should be done when they heard the warning, where and how to save themselves; (4) Disaster warning system, especially tsunami. The system includes warning signs and information distribution about the disaster. The warning system could lead the community to take appropriate actions in reducing the risks; (5) Resources Mobilization. Resources such as people, funding, and facilities can support or otherwise become the obstacles in natural disaster preparedness.

The use of animation video is adjusted to the characteristics of students who still connect concrete materials in the daily life presented. In addition, the animation video provides a chance for students to be more active in the learning process. The video could also be used by the teacher in presenting preparedness learning material, starting from pre disaster, during the disaster, and post disaster.

The hypothesis of this study is formulated as follow:

Ho : "Siaga Tsunami" animation video does not influence the disaster preparedness of the students of SDN 01 Cigondang, Pandeglang
$\mathrm{Ha}$ : "Siaga Tsunami" animation video influence the disaster preparedness of the students of SDN 01 Cigondang, Pandeglang.

\section{Research Methodology}

The study was conducted using a quantitative approach with the positivist paradigm. The experimental method was also employed in this study. According to Sugiyono, "Experimental research method is used to determine the effect of a certain treatment on an object in a controlled condition" (Sugiyono, 2016).

This research population is students of SDN 01 Cigondang, Pandeglang, Banten. The samples are 114 students of grade IV, $V$, and VI which categorized as higher grades and included in the concrete operational stage (10-12 years old). The samples were divided into two groups: group A consisted of 58 students, and group B consisted of 57 students. Group A was the treatment group treated by the "Siaga Tsunami" animation video and group B was the control group treated by the "Siaga Tsunami" pictorial story.

The design used was Pretest-Posttest Control Group Design in order to simplify the steps in conducting the research. The design is also the result of the hypothesis and it compares the preliminary test and final test. The experiment design of this research is shown on the Table 1 .

\section{Table 1}

Pretest-Posttest Control Group Design

\begin{tabular}{lccc}
\hline & Pretest & Treatment & Posttest \\
\hline Experiment & $\mathrm{O}_{1}$ & $\mathrm{X}_{1}$ & $\mathrm{O}_{2}$ \\
Group & $\mathrm{O}_{3}$ & $\mathrm{X}_{2}$ & $\mathrm{O}_{4}$ \\
Control Group & $\mathrm{O}_{3}$ & & \\
\hline
\end{tabular}

Explanation:

$\mathrm{O}_{1}=$ Preliminary ability test on the preparedness of the experiment class' students

$\mathrm{O}_{2}=$ Final ability test on the preparedness of the experiment class' students

$\mathrm{O}_{3}=$ Preliminary ability test on the preparedness of the control class' students

$\mathrm{O}_{4}=$ Final ability test on the preparedness of the control class' students

$\mathrm{X}_{1}=$ using "SiagaBencana Tsunami" animation video

$\mathrm{X}_{2}=$ using "SiagaBencana Tsunami" pictured postermedia

In this research, the independent variable $(X)$ is the variable whose effect was studied on the "Siaga Tsunami" animation 
video, and the dependent variable $(Y)$ is the preparedness of the students of SDN 01 Cigondang.

The technique in collecting data was explained as follow: primary data were gained through test and questionnaire. The test is a right-wrong test given during the pretest and posttest. The method enables the researcher to gain data that are useful in measuring the students' knowledge of preparedness. The test showed the difference between the control class and experiment class in students' ability during the treatment.

The questionnaire was given to examine the preparedness of the students in dealing with the tsunami. The questionnaire used is a rating scale. Research instrument testing was conducted in SDN 01 Cigondang. Biserial formula is used for the results of validity test and Kuder Richardson 20 (KR20) formula is used for reliability test.

The data were analyzed by both descriptive statistics and inferential statistics. Descriptive statistics were used to describe the preparedness level of the students, while inferential statistics, especially non parametric test, were used to test the score difference between the experiment group (animation video) and the control group (pictorial story) (Sulaiman, 2003).

\section{Results and Discussion}

The subjects of this study are the students of grade IV, V, and VI of SDN 01 Cigondang, Pandeglang (NPSN 20601439), which is located at Cigondang Mesjid, Cigondang Village, Labuan District, Pandeglang, Banten. The subjects in the experiment group are 57 students: 23 male students and 34 female students, while the subjects in the control group are 57 students:
34 male students and 23 female students. Most of the respondents are 10 and 11 years old $(28.1 \%)$; while in video group, most of the respondents are 11 years old (35.1\%). In the pictorial group, most of the respondents are male (59.6\%); and in video group, most of the respondents are female (59.6\%).

\section{Treatment}

The media used in the control group were pictorial story of a tsunami as in figure 1 .

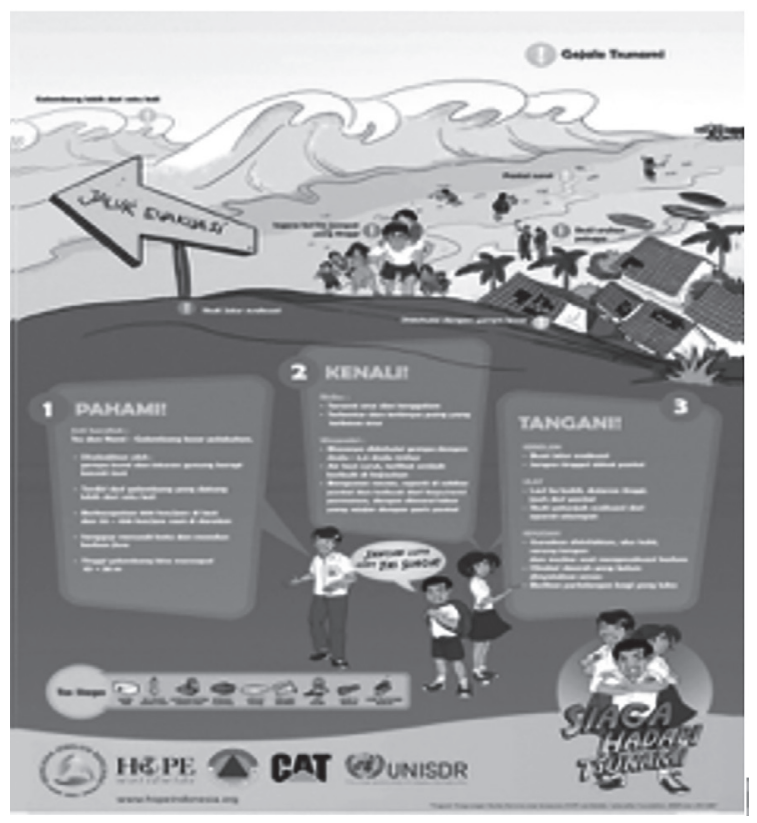

Figure 1. Siaga Tsunami

\section{Experiment Group}

Animation media was used in the experiment group. The duration of its presentation was four minutes. After the video was presented, the researcher conducted a discussion which aimed to take up the material in the video.

Table 2

The Results of Pretest and Post Test of Experiment and Control Group

\begin{tabular}{|c|c|c|c|c|c|}
\hline \multirow[b]{2}{*}{ No } & \multirow[b]{2}{*}{ Questions } & \multicolumn{2}{|c|}{$\begin{array}{l}\text { PICTURES } \\
\text { TREATMENT }\end{array}$} & \multicolumn{2}{|c|}{$\begin{array}{c}\text { VIDEO } \\
\text { TREATMENT }\end{array}$} \\
\hline & & Before & After & Before & After \\
\hline & Knowledge aspects of Disaster & Correct & Correct & Correct & Correct \\
\hline 1 & $\begin{array}{l}\text { Natural disaster is a natural phenomenon that } \\
\text { disturbs human and their life }\end{array}$ & $54 \%$ & $72 \%$ & $68 \%$ & $98 \%$ \\
\hline 2 & $\begin{array}{l}\text { Natural phenomena which can cause disaster are } \\
\text { earthquake and tsunami }\end{array}$ & $72 \%$ & $61 \%$ & $79 \%$ & $98 \%$ \\
\hline 3 & Every earthquake creates tsunami & $81 \%$ & $74 \%$ & $56 \%$ & $54 \%$ \\
\hline
\end{tabular}




\begin{tabular}{|c|c|c|c|c|c|}
\hline 4 & $\begin{array}{l}\text { Earthquakes, volcano eruption, and landslide that } \\
\text { occur under the sea are caused by tsunami }\end{array}$ & $0 \%$ & $53 \%$ & $11 \%$ & $100 \%$ \\
\hline 5 & Sudden water receding is the sign of a tsunami & $0 \%$ & $100 \%$ & $0 \%$ & $100 \%$ \\
\hline 6 & $\begin{array}{l}\text { If the water recedes, we must stay away from } \\
\text { the sea }\end{array}$ & $0 \%$ & $100 \%$ & $0 \%$ & $100 \%$ \\
\hline 7 & $\begin{array}{l}\text { To be more prepared, you need to improve your } \\
\text { knowledge of tsunami }\end{array}$ & $2 \%$ & $47 \%$ & $0 \%$ & $98 \%$ \\
\hline 8 & $\begin{array}{l}\text { Have you known or experienced Sunda Strait } \\
\text { Tsunami in } 2018\end{array}$ & $0 \%$ & $75 \%$ & $0 \%$ & $26 \%$ \\
\hline 9 & $\begin{array}{l}\text { Have you received any lesson about tsunami at } \\
\text { school }\end{array}$ & $0 \%$ & $100 \%$ & $0 \%$ & $98 \%$ \\
\hline 10 & $\begin{array}{l}\text { Have you received knowledge about disaster } \\
\text { warning, first aid, rescue and evacuation }\end{array}$ & $0 \%$ & $77 \%$ & $0 \%$ & $100 \%$ \\
\hline 11 & $\begin{array}{l}\text { Listen to information regarding tsunami through } \\
\text { radio, tv, and internet }\end{array}$ & $0 \%$ & $37 \%$ & $0 \%$ & $100 \%$ \\
\hline 12 & Knowledge about disaster is gained at school & $100 \%$ & $98 \%$ & $98 \%$ & $100 \%$ \\
\hline 13 & $\begin{array}{l}\text { Knowledge about disaster is gained through } \\
\text { printed media (newspaper, magazines) and } \\
\text { electronic media (radio, tv, internet) }\end{array}$ & $0 \%$ & $14 \%$ & $0 \%$ & $44 \%$ \\
\hline \multirow[t]{2}{*}{14} & $\begin{array}{l}\text { Knowledge about disaster is gained through } \\
\text { books, comics, leaflet, and information board }\end{array}$ & $19 \%$ & $82 \%$ & $42 \%$ & $100 \%$ \\
\hline & Emergency Response Planning & & & & \\
\hline 15 & $\begin{array}{l}\text { Books, posters, comics, and CDs about tsunami } \\
\text { could be easily accessed at school }\end{array}$ & $0 \%$ & $37 \%$ & $68 \%$ & $68 \%$ \\
\hline 16 & There are evacuation map and route at school & $28 \%$ & $46 \%$ & $39 \%$ & $100 \%$ \\
\hline 17 & The school has its own Red Cross Unit & $2 \%$ & $0 \%$ & $0 \%$ & $0 \%$ \\
\hline 18 & The school has disaster safe group & $0 \%$ & $0 \%$ & $0 \%$ & $0 \%$ \\
\hline 19 & $\begin{array}{l}\text { Join self-rescue training, acknowledge safe } \\
\text { places, note important addresses and numbers, } \\
\text { acknowledge important places such as hospital, } \\
\text { firefighter office, police station, PMI, and PLN are } \\
\text { the efforts that can be done to anticipate tsunami }\end{array}$ & $72 \%$ & $100 \%$ & $100 \%$ & $100 \%$ \\
\hline 20 & $\begin{array}{l}\text { If the tsunami occurs, we should rescue ourselves, } \\
\text { report, take school bag, important documents, } \\
\text { and letters }\end{array}$ & $91 \%$ & $100 \%$ & $100 \%$ & $100 \%$ \\
\hline \multirow[t]{2}{*}{21} & Favorite items should be rescued & $91 \%$ & $60 \%$ & $68 \%$ & $67 \%$ \\
\hline & Disaster Warning & & & & \\
\hline 22 & $\begin{array}{l}\text { Acknowledge the signs for tsunami (kentongan/ } \\
\text { bedug/siren) }\end{array}$ & $2 \%$ & $100 \%$ & $0 \%$ & $100 \%$ \\
\hline 23 & $\begin{array}{l}\text { Acknowledge the tools/signs/sound for tsunami } \\
\text { warning at school }\end{array}$ & $0 \%$ & $42 \%$ & $0 \%$ & $100 \%$ \\
\hline 24 & $\begin{array}{l}\text { Understand that tsunami warning could be } \\
\text { canceled (when there is no tsunami) }\end{array}$ & $0 \%$ & $0 \%$ & $0 \%$ & $100 \%$ \\
\hline 25 & $\begin{array}{l}\text { Understand the information when the situation is } \\
\text { safe after the tsunami has occurred }\end{array}$ & $0 \%$ & $46 \%$ & $0 \%$ & $100 \%$ \\
\hline 26 & $\begin{array}{l}\text { Have you joined training or simulation on disaster } \\
\text { warning }\end{array}$ & $32 \%$ & $37 \%$ & $32 \%$ & $100 \%$ \\
\hline \multirow[t]{2}{*}{27} & $\begin{array}{l}\text { If I hear the sign for tsunami, I will stay away } \\
\text { from the coast and go to a higher land without } \\
\text { panicking }\end{array}$ & $2 \%$ & $60 \%$ & $0 \%$ & $100 \%$ \\
\hline & Resource Mobilization & & & & \\
\hline
\end{tabular}




\begin{tabular}{|c|c|c|c|c|c|}
\hline 28 & $\begin{array}{l}\text { Have you joined activity or lecture regarding } \\
\text { tsunami }\end{array}$ & $0 \%$ & $100 \%$ & $0 \%$ & $100 \%$ \\
\hline 29 & Have you joined activity or rescue simulation & $33 \%$ & $37 \%$ & $32 \%$ & $100 \%$ \\
\hline 30 & Have you joined Red Cross & $0 \%$ & $0 \%$ & $0 \%$ & $0 \%$ \\
\hline
\end{tabular}

Table 3

Pretest Result

\begin{tabular}{|c|c|c|c|c|c|c|c|c|c|}
\hline & \multicolumn{3}{|c|}{ CONTROL GROUP } & \multicolumn{3}{|c|}{ EXPERIMENT GROUP } & \multicolumn{3}{|c|}{ SUBJECT } \\
\hline & MEAN & IDX & $\begin{array}{l}\text { COEFFI- } \\
\text { CIENT }\end{array}$ & MEAN & IDX & $\begin{array}{l}\text { COEFF- } \\
\text { ICIENT }\end{array}$ & MEAN & IDX & $\begin{array}{l}\text { COEFFI- } \\
\text { CIENT }\end{array}$ \\
\hline $\begin{array}{l}\text { DISASTER KNOWLEDGE } \\
(35)\end{array}$ & 3,28 & 0,57 & 114,82 & 3,54 & 0,64 & 124,04 & 3,41 & 0,60 & 119,43 \\
\hline $\begin{array}{l}\text { EMERGENCY RESPONSE } \\
\text { PLANNING (15) }\end{array}$ & 0,33 & 0,18 & 42,63 & 0,32 & 0,16 & 56,32 & 0,32 & 0,17 & 49,47 \\
\hline EARLY WARNING (25) & 0,35 & 0,50 & 8,77 & 0,32 & 0,16 & 7,89 & 0,33 & 0,33 & 8,33 \\
\hline $\begin{array}{l}\text { RESOURCE MOBILIZATION } \\
\text { (15) }\end{array}$ & 0,33 & 0,33 & 5,00 & 0,32 & 0,32 & 4,74 & 0,32 & 0,32 & 4,87 \\
\hline $\begin{array}{l}\text { DISASTER PREPAREDNESS } \\
\text { INDEX }\end{array}$ & & & 171,23 & & & 192,98 & & & 182,11 \\
\hline status & & & $\begin{array}{l}\text { Unpre- } \\
\text { pared }\end{array}$ & & & $\begin{array}{l}\text { Unpre- } \\
\text { pared }\end{array}$ & & & $\begin{array}{l}\text { Unpre- } \\
\text { pared }\end{array}$ \\
\hline
\end{tabular}
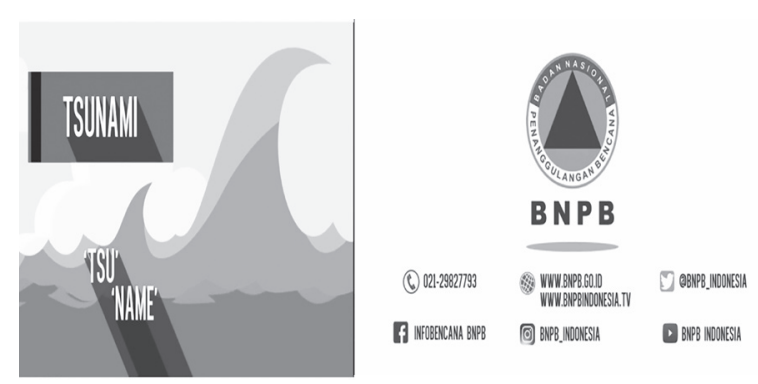

Figure 2. Siaga tsunami Video

As we can seen in figure 2 explain about student preparedness in facing Tsunami disaster in disaster prone schools.

\section{Descriptive Analysis of Students' Preparedness Level}

The results of pre-test and post-test of both experimental group and control group are presented in Table 2.

There are several points gained through the Table 2. First, two questions never changed on both the experiment group and control group which scored zero (0). The score showed that: (1) There is no disaster safe group at school; (2) The subjects never joined the Red Cross. The information is essential to decide the next relevant step for BNPB.

Second, there are changes in the scores of several questions from zero (0) to above after the treatment given to both groups. Before the treatment, the subjects did not know that "knowledge about disaster can be gained through printed media (newspaper, magazines) and electronic media (radio, tv, internet)". After the treatment, several subjects ( $14 \%$ of the control group and $44 \%$ of the experiment group) could acknowledge that. Another sample: Before the treatment, $0 \%$ of the subjects knew that "Sudden water receding is the sign of tsunami". After the treatment, $100 \%$ of the subjects acknowledged the fact. The Disaster Preparedness Index of each dimension pretest is presented in Table 3 .

$\mathrm{IKB}=35(\mathrm{PS})+15$ (RTD) $+25(\mathrm{SPB})+15$ (MS)

On the pre-test stage, both groups were unprepared. Thus, in general, the subjects' status was unprepared. The Disaster Preparedness Index of each dimension posttest is presented in Table 4.

$\mathrm{IKB}=35$ (PS) +15 (RTD) +25 (SPB) +15 (MS)

On the post-test stage, both groups were in different positions. The experiment 
Table 4

Post Test Result

\begin{tabular}{|c|c|c|c|c|c|c|c|c|c|}
\hline & \multicolumn{3}{|c|}{ CONTROL GROUP } & \multicolumn{3}{|c|}{ EXPERIMENT GROUP } & \multicolumn{3}{|c|}{ SUBJECT } \\
\hline & MEAN & IDX & $\begin{array}{l}\text { COEFFI- } \\
\text { CIENT }\end{array}$ & MEAN & IDX & $\begin{array}{l}\text { COEFFI- } \\
\text { CIENT }\end{array}$ & MEAN & IDX & $\begin{array}{l}\text { COEFFI- } \\
\text { CIENT }\end{array}$ \\
\hline $\begin{array}{l}\text { DISASTER KNOWLEDGE } \\
\text { (35) }\end{array}$ & 9,91 & 0,49 & 346,93 & 12,18 & 0,77 & 426,14 & 11,04 & 0,63 & 386,54 \\
\hline $\begin{array}{l}\text { EMERGENCY RESPONSE } \\
\text { PLANNING (15) }\end{array}$ & 3,42 & 0,47 & 58,29 & 4,35 & 0,78 & 65,26 & 3,89 & 0,63 & 61,78 \\
\hline EARLY WARNING (25) & 2,84 & 0,37 & 71,05 & 6,00 & 1,00 & 150,00 & 4,42 & 0,68 & 110,53 \\
\hline $\begin{array}{l}\text { RESOURCE MOBILIZATION } \\
(15)\end{array}$ & 1,37 & 0,37 & 20,53 & 2,00 & 1,00 & 30,00 & 1,68 & 0,68 & 25,26 \\
\hline $\begin{array}{l}\text { DISASTER PREPAREDNESS } \\
\text { INDEX }\end{array}$ & & & 496,80 & & & 671,40 & & & 584,10 \\
\hline status & & & $\begin{array}{l}\text { Nearly } \\
\text { pre- } \\
\text { pared }\end{array}$ & & & $\begin{array}{l}\text { Prepa- } \\
\text { red }\end{array}$ & & & $\begin{array}{l}\text { Prepa- } \\
\text { red }\end{array}$ \\
\hline
\end{tabular}

group was prepared; meanwhile, the control group was nearly prepared. The combined scores of both groups, in general, showed that they were prepared.

Based on the variable dimensions of disaster preparedness knowledge, four hypotheses were formulated. Each was tested with Mann-Whitney $U$ and Wilcoxon W testing procedures as the data were categorized as data for the non-parametric test. The results are presented in Table 5 .

Table 5

The Result of Hypothesis Test on Disaster Knowledge Pretest Score

\begin{tabular}{ll}
\hline & $\begin{array}{l}\text { Disaster Knowledge } \\
\text { Pre-Test Score }\end{array}$ \\
\hline Mann-Whitney U & 1367.000 \\
Wilcoxon W & 3020.000 \\
Z & -1.544 \\
$\begin{array}{l}\text { A s y m p. S i g . } \\
\text { (2-tailed) }\end{array}$ & .123
\end{tabular}

The table 5 shows that Asymp. Sig. (2-tailed) $=0.123(>0.05)$. Therefore, the $\mathrm{H}_{\mathrm{a}}$ is rejected. This implied that there were no statistically significant differences between the mean score of disaster knowledge dimension in the experiment group and the control group. It was due to the subjects that were not given the treatment (both picture and video animation). The results of hypothesis test on disaster knowledge post test score are presented in Table 6.

Table 6

The Result of Hypothesis Test on Disaster Knowledge Post-Test Score

\begin{tabular}{ll}
\hline & $\begin{array}{l}\text { Disaster Knowledge } \\
\text { Post-Test Score }\end{array}$ \\
\hline Mann-Whitney U & 404.500 \\
Wilcoxon W & 2057.500 \\
Z & -7.039 \\
A s y m p. S i g. & .000 \\
(2-tailed) & \\
\hline
\end{tabular}

The Table 6 showed Asymp. Sig. (2-tailed) $=0,000(<0,05)$. Therefore, the $\mathrm{H}_{\mathrm{a}}$ is accepted. This implied that there were statistically significant differences between the mean score of the disaster knowledge dimension in the experiment group and the control group. Hence, it can be concluded that different treatments given to the experimental subjects affected the disaster knowledge dimension.

The result of hypothesis test on emergency response planning pre test score are presented in Table 7.

Table 7

The Result of Hypothesis Test on

Emergency Response Planning PreTest Score

\begin{tabular}{ll}
\hline & $\begin{array}{l}\text { Emergency Response } \\
\text { Planning Pre-Test Score }\end{array}$ \\
\hline Mann-Whitney U & 714.000 \\
Wilcoxon W & 2367.000 \\
$Z$ & -5.603 \\
Asymp. Sig. (2-tailed) & .000 \\
\hline \multicolumn{2}{c}{ The Table $7 \quad$ showed Asymp. Sig. } \\
(2-tailed) = 0,000 (< 0,05$)$. Therefore, the \\
$\mathrm{H}_{\mathrm{a}}$ is accepted.This implied that there were
\end{tabular}


statistically significant differences between the mean score of emergency response planning in the experiment group and the control group. This could be caused by other factors outside the treatment since it was not being given. The result of hypothesis test on emergency response planning post test score are presented in Table 8.

Table 8

The Result of Hypothesis Test on Emergency Response Planning PostTest Score

\begin{tabular}{ll}
\hline & $\begin{array}{l}\text { Emergency Response } \\
\text { Planning Post-Test } \\
\text { Score }\end{array}$ \\
\hline Mann-Whitney U & 624.000 \\
Wilcoxon W & 2277.000 \\
Z & -6.042 \\
Asymp. Sig. (2-tailed) & .000 \\
\hline
\end{tabular}

The Table 8 showed Asymp. Sig. $(2$-tailed $)=0,000(<0,05)$. Therefore, the $\mathrm{H}_{\mathrm{a}}$ is accepted. This implied that there were statistically significant differences between the mean score of emergency response planning in the experiment group and the control group.

Hence, it can be concluded that different treatments given to experimental subjects affected the emergency response planning dimension. The result of hypothesis test on Early Warning pre test score are presented in Table 9.

Table 9

The Result of Hypothesis Test on Early Warning Pre-Test Score

\begin{tabular}{ll}
\hline & $\begin{array}{l}\text { Early Warning Pretest } \\
\text { Score }\end{array}$ \\
\hline Mann-Whitney U & 1606.500 \\
Wilcoxon W & 3259.500 \\
Z & -.126 \\
$\begin{array}{l}\text { Asymp. Sig. } \\
\text { (2-tailed) }\end{array}$ & .900 \\
\hline
\end{tabular}

The Table 9 shows Asymp. Sig. $(2$-tailed $)=0.123(>0.05)$. Therefore, the $\mathrm{H}_{\mathrm{a}}$ is rejected. This implied that there were no statistically significant differences between the mean score of early warning in the experiment group and the control group.

This could be caused by other factors outside the treatment since it was not being given. The result of hypothesis test on early warning post test score are presented in Table 10.
Table 10

The Result of Hypothesis Test on Early Warning Post-Test Score

\begin{tabular}{ll}
\hline & $\begin{array}{l}\text { Early Warning Post Test } \\
\text { Score }\end{array}$ \\
\hline Mann-Whitney U & .000 \\
Wilcoxon W & 1653.000 \\
Z & -9.900 \\
Asymp. Sig. (2-tailed) & .000 \\
\hline
\end{tabular}

The Table 10 showed Asymp. Sig. $(2$-tailed $)=0,000(<0,05)$. Therefore, the $\mathrm{H}_{\mathrm{a}}$ is accepted. This implied that there were statistically significant differences between the mean score of early warning in the experiment group and the control group.

Hence, it can be concluded that different treatments given to experimental subjects affected the early warning dimension. The result of hypothesis test on resource mobilization pre test score are presented in Table 11.

Table 11

The Result of Hypothesis Test on Resource Mobilization Pre Test Score

\begin{tabular}{ll}
\hline & $\begin{array}{l}\text { Resource Mobilization } \\
\text { Pre Test Score }\end{array}$ \\
\hline Mann-Whitney U & 1596.000 \\
Wilcoxon W & 3249.000 \\
Z & -.199 \\
Asymp. Sig. (2-tailed) & .842 \\
\hline
\end{tabular}

The Table 11 shows Asymp. Sig. $(2$-tailed $)=0.123$ ( $>0.05)$. Therefore, the $\mathrm{H}_{\mathrm{a}}$ is rejected. This implied that there were no statistically significant differences between the mean score of resource mobilization in the experiment group and the control group. This could be caused by other factors outside the treatment since it was not being given. The result of hypothesis test on resource mobilization post test score are presented in Table 12.

Table 12

The Result of Hypothesis Test on Resource Mobilization Post Test Score

\begin{tabular}{ll}
\hline & $\begin{array}{l}\text { Resource Mobilization } \\
\text { Post Test Score }\end{array}$ \\
\hline Mann-Whitney U & 598.500 \\
Wilcoxon W & 2251.500 \\
Z & -7.222 \\
Asymp. Sig. (2-tailed) & .000 \\
\hline
\end{tabular}

The Table 12 showed Asymp. Sig. 
(2-tailed) $=0,000(<0,05)$. Therefore, the $\mathrm{H}_{\mathrm{a}}$ is accepted. This implied that there were statistically significant differences between the mean score of resource mobilization in the experiment group and the control group. Hence, it can be concluded that different treatments given to experimental subjects affected the resource mobilization dimension.

The differences between the pre-test and post-test scores above would be further tested. The Wilcoxon Signed Ranks Test is used to test the score before and after the treatment in the experimental and control groups. The result of mean score of dimension of disaster preparedness are presented in Table 13.

Table 13

The Mean Score of Dimensions of Disaster Preparedness

\begin{tabular}{llll}
\hline & & \multicolumn{2}{l}{ Mean } \\
\cline { 2 - 3 } $\begin{array}{l}\text { DIMENSIONS } \\
\begin{array}{l}\text { OF DISASTER } \\
\text { PREPAREDNESS }\end{array}\end{array}$ & $\mathrm{N}$ & $\begin{array}{l}\text { Picture } \\
\text { Group } \\
\text { Gambar }\end{array}$ & $\begin{array}{l}\text { Video } \\
\text { Group }\end{array}$ \\
\hline $\begin{array}{l}\text { Score of Disaster } \\
\text { Knowledge-Pre }\end{array}$ & 57 & 3,28 & 3,54 \\
\hline $\begin{array}{l}\text { Score of } \\
\text { Emergency }\end{array}$ & 57 & 2,84 & 3,75 \\
$\begin{array}{l}\text { Response } \\
\text { Planning-Pre }\end{array}$ & & & \\
\hline $\begin{array}{l}\text { Score of Early } \\
\text { Warning -Pre }\end{array}$ & 57 &, 35 &, 32 \\
\hline $\begin{array}{l}\text { Score of Resource } \\
\text { Mobilization-Pre }\end{array}$ & 57 &, 33 &, 32 \\
\hline $\begin{array}{l}\text { Score of Disaster } \\
\text { Knowledge-Post }\end{array}$ & 57 & 6,21 & 8,47 \\
\hline $\begin{array}{l}\text { Score of } \\
\text { Emergency }\end{array}$ & 57 & 3,42 & 4,35 \\
$\begin{array}{l}\text { Response } \\
\text { Planning-Post }\end{array}$ & & & \\
\hline $\begin{array}{l}\text { Score of Early } \\
\text { Warning-Post }\end{array}$ & 57 & 2,84 & 6,00 \\
\hline $\begin{array}{l}\text { Score of Resource } \\
\text { Mobilization-Post }\end{array}$ & 57 & 1,37 & 2,00 \\
\hline
\end{tabular}

Note: -Pre (Pre-test) -Post (Post-test)

The Table 13 shows an increase in scores, except for the dimensions of Disaster Response and Early Warning which have lower scores (around 0.01.-0.03). The test results below show the significance of the difference in scores.

The result of hypothesis test on four dimension of disaster preparedness are presented in Table 14. The Table 14 shows Asymp. Sig. (2-tailed) $=0,000(<0.05)$. This implied that in all four dimensions of disaster preparedness, $\mathrm{H}_{\mathrm{o}}$ (the median of the experimental group and the control group are the same) is rejected. Thus, it can be concluded that the differences in scores on each dimension occurs due to treatment issues, both in the experimental group (animation video) and the control group (picture).

Similar conclusions can also be seen in testing the total score of disaster preparedness before and after the experimental and control groups, as shown in the Table 15.

The Table 15 shows Asymp. Sig. $(2$-tailed $)=0,000(<0.05)$. This implied that $\mathrm{H}_{\mathrm{o}}$ (the median of the experimental group and the control group are the same) is rejected. Thus, it can be concluded that the differences in the score of disaster preparedness before and after in the experimental group (mean: 7,93 became 20,82) and the control group (mean: 6,81 became 13,84) due to the treatment issues. In other words, animated videos influence disaster preparedness on the subject of experiment.

From the perspective of SOR theory, the findings provide empirical data about stimuli (animated videos and images). When the stimulus is different, the response will also be different. The stimulus of video animation increases disaster preparedness' score more than picture stimulus. This finding is in line with the findings of Sari, Elianora, and Bakar who revealed the mean knowledge of SDN 027 Sungai Sapih Kec. Kuranji, Padang. The highest group was the one who watched animation scored 13.79 , compared to those who watch the video scored 3.58 (Sari, Elanora, \& Bakar, 2017). This finding is also in accordance with Davidson et al., who stated that watching the video is a way to tell events to others (Davidson et al., 2014). In this context, individuals who watch animated videos report their responses on the dimensions of disaster preparedness.

One of the media that is quite relevant in fostering a sense of preparedness is an animated video because there are motion pictures and sounds. Animation can provide a more meaningful learning experience and provide a greater stimulus than reading a textbook because the message is in the form of audiovisual and the movement in an animated video gives an impressive image to the audience.

The treatment given to the control group is to provide learning with picture and 
Table 14

The Result of Hypothesis Test on Four Dimensions of Disaster Preparedness

\begin{tabular}{|c|c|c|c|c|c|}
\hline \multicolumn{6}{|c|}{ Test ofStatistics ${ }^{a}$} \\
\hline \multicolumn{2}{|c|}{ TREATMENT GROUP } & $\begin{array}{l}\text { Score of Disaster } \\
\text { Knowledge } \\
\text {-POST - Score } \\
\text { of Disaster } \\
\text { Knowledge -PRE }\end{array}$ & $\begin{array}{l}\text { Score of } \\
\text { Emergency } \\
\text { Response } \\
\text { Planning- } \\
\text { POST - Score } \\
\text { of Emergency } \\
\text { Response } \\
\text { Planning-PRE }\end{array}$ & $\begin{array}{l}\text { Score of } \\
\text { EarlyWarning- } \\
\text { POST - } \\
\text { Score of } \\
\text { EarlyWarning- } \\
\text { PRE }\end{array}$ & $\begin{array}{l}\text { Score of } \\
\text { Resource } \\
\text { Mobilization- } \\
\text { POST - Score } \\
\text { of Resource } \\
\text { Mobilization- } \\
\text { PRE }\end{array}$ \\
\hline \multirow{3}{*}{ Control Group } & 7 & & $3030 \mathrm{~b}$ & & \\
\hline & 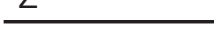 & & . & 0,007 & $-1,4<9^{\circ}$ \\
\hline & $\begin{array}{l}\text { Asymp. Sig. } \\
\text { (2-tailed) }\end{array}$ & ,000 & ,000 & ,000 & ,000 \\
\hline \multirow{2}{*}{$\begin{array}{l}\text { Experimental } \\
\text { Group }\end{array}$} & Z & $-6,682^{b}$ & $-5,667^{b}$ & $-6,867^{b}$ & $-6,867^{b}$ \\
\hline & $\begin{array}{l}\text { Asymp. Sig. } \\
\text { (2-tailed) }\end{array}$ &, 000 &, 000 &, 000 &, 000 \\
\hline
\end{tabular}

a. Wilcoxon Signed Ranks Test

b. Based on negative ranks.

Table 15

The Result of Hypothesis Test on Animated Video and Disaster Preparedness TREATMENT GROUP

Preparedness Score-Pre

\begin{tabular}{lll}
\hline Control Group & Z & $-6,587^{\mathrm{b}}$ \\
\hline & Asymp. Sig. (2-tailed) &, 000 \\
\hline Experimental Group & Z & $-6,602^{\mathrm{b}}$ \\
\hline & Asymp. Sig. (2-tailed) &, 000 \\
\hline a. Wilcoxon Signed Ranks Test & & \\
\hline b. Based on negative ranks & & \\
\hline
\end{tabular}

poster media, while the experiment group is given the animated video. Based on the results of the post-test, it is found that the animation video is more significant and effective in increasing student preparedness in SDN 01 Cigondang compared to the pictorial storybook.

Furthermore, regarding the concept of organisms (O), Dollard and Miller believe that it can react to the same stimulus with different responses (Ellis, Abrams, \& Abrams, 2009). This proposition seems to be supported in part by this research data. Through MannWhitney $U$ test on disaster preparedness scores (without discriminating the treatment), it was found that the female group had the highest mean rank (64.27) compared to male (50.73). The Mann-Whitney U score test = 1238.5 (Asymp. Sig. [2-tailed] $=0.027$ ). Thus, $\mathrm{H}_{\mathrm{o}}$ was rejected, which can be concluded that the Disaster Preparedness Score after the provision of treatments in the female group was statistically and significantly higher than the male group.

In other cases, where the characteristics of the organism are the class of subjects (grades 4 and 6, for example), the following test results are obtained. Overall, by applying the Mann-Whitney $U$ test on disaster preparedness scores (without discriminating the treatment), it was found that the group of grade 6 students (51.50) had an mean rank higher than the group of grade 4 students (38.92). The Mann-Whitney U score test $=709,500$ (Asymp. Sig. [2-tailed] = 0, 020). Thus, $H_{0}$ was rejected, meaning that the Disaster Preparedness Score after the provision of treatments in the group of grade 6 students was statistically and significantly higher than the group of grade 4 students.

The cases tested above confirm the importance of organism concept in learning. This view is relatively in line with Tolman (1948, p. 189) who discusses the "role of the 
organism" in information processing that can be either active or passive (Holland, 2011).

\section{Conclusions}

The use of animation video in learning process can give a positive influence on disaster preparedness knowledge. The media can stimulate students' motivation and interest in learning. In addition, the learning method with animation video presentations could encourage the students to absorb more knowledge on disaster preparedness. The final result of this study shows that there is an influence of animation video on the preparedness knowledge of the students of SDN 01 Cigondang, Pandeglang. It is concluded that the treatment with animation video media is more effective than picture media.

The recommendation of this study is that the socialization of disaster preparedness is very crucial to be delivered to children. The more effective media is animation video that can make us go deeper into the character of children.

\section{Acknowledgment}

The researchers would like to thank Rector Universitas Mercu Buana for material support. We would also like to thank Yunita Sari for helping us collecting the data for this research.

\section{References}

Ahmadi, Dadi, Sabarina, C., \& Harahap, E. H. (2020). Implementation Information Technology Through Channel Youtube "Lampu Islam." 409 (SoRes 2019), 630-631. https://doi.org/10.2991/ assehr.k.200225.137

Alhadi, Z., \& Sasmita, S. (2014). Kesiapsiagaan Masyarakat Kota Padang Dalam Menghadapi Resiko Bencana Gempa Dan Tsunami Berbasis Kearifan Lokal (Studi Kesiapsiagaan Terhadap Resiko Bencana). Humanus. https://doi.org/10.24036/ jh.v13i2.4726

Araújo, C. S., Magno, G., Meira, W., Almeida, V., Hartung, P., \& Doneda, D. (2017). Characterizing videos, audience and advertising in youtube channels for kids. In Lecture Notes in Computer Science (including subseries Lecture Notes in Artificial Intelligence and Lecture
Notes in Bioinformatics). https://doi. org/10.1007/978-3-319-67217-5_21

Arif, M. (2018). Kesiapsiagaan Masyarakat Kawasan Perkotaan Terhadap Bencana Gempa Bumi. Jurnal Planologi Unpas. https://doi.org/10.23969/planologi. v5i1.928

Bronto, S. (2006). Fasies gunung api dan aplikasinya. Indonesian Journal on Geoscience. https://doi.org/10.17014/ ijog.vol1no2.20061

Burroughs, B. (2017). Youtube kids: The app economy and mobile parenting. Social Media and Society. https://doi. org/10.1177/2056305117707189

Damayanti, H. N. (2015). Kajian Kesiapsiagaan Individu dan Rumah Tangga Dalam Menghadapi Bencana Tsunami Di Kecamatan Grabag Kabupaten Purworejo. Fakultas IImu Sosial.

Daud, R., Sari, S. A., Milfayetty, S., \& Dirhamsyah, M. (2014). Penerapan Pelatihan Siaga Bencana dalam Meningkatkan Pengetahuan, Sikap, dan Tindakan Komunitas SMA Negeri 5 Banda Aceh. Jurnal Ilmu Kebencanaan (JIKA).

Davidson, C., Given, L. M., Danby, S., \& Thorpe, K. (2014). Talk about a YouTube video in preschool: The mutual production of shared understanding for learning with digital technology. Australasian Journal of Early Childhood. https://doi. org/10.1177/183693911403900310

Dewi, R. K., \& Hardiyanto, S. (eds). (2020). Terasa hingga Sukabumi, Gempa M 4,9 di Lebak Banten Tak Berpotensi Tsunami. Retrieved from https://www.kompas. com/tren/read/2020/02/17/203053665/ terasa-hingga-sukabumi-gempa-m49-di-lebak-banten-tak-berpotensitsunami?page $=$ all.

Ellis, A., Abrams, M., \& Abrams, L. (2009). Personality Theories: Critical Perspectives. SAGE Publications, Inc. Retrieved from https://books.google.co.id/books?id =4 FOIKi2_tYC\&dq=stimulus+organism+re sponse+theory\&source=gbs_navlinks_s

Everhart, J. (2009). YouTube in the Science Classroom. Science and Children.

Holland, P. C. (2011). NIH Public Access, 36(3), 227-241. Retrieved from https:// www.ncbi.nlm.nih.gov/pmc/articles/ PMC3065938/pdf/nihms190745.pdf

Hourcade, J. P., Mascher, S. L., Wu, D., \& Pantoja, L. (2015). Look, my baby is using an iPad! An analysis of youtube videos of infants and toddlers using tablets. In Conference on Human Factors in Computing Systems - Proceedings. https:// 
doi.org/10.1145/2702123.2702266

I Gusti Agung Haryawan, Ni Luh Gede Aris Maytadewi Negara, \& N. K. P. P. D. (2012). Kajian Kesiapsiagaan Penanggulangan Bencana Gempa Bumi Bagi Pekerja Pada Gedung Bertingkat Di Denpasar.

Ismayani, N. (2019). Kesiapsiagaan Terhadapi Bencana Gempa Dan Tsunami (Kampung Koto Nagari Sungai Pisang Kabupaten Pesisir Selatan). Jurnal Pengabdian Kepada Masyarakat Dewantara.

Johnson, B. (2019). Animation. In Persons and Things. https://doi.org/10.2307/j. ctvk12sgc. 15

Kholisoh, N. (2018). Media Literacy Training For Senior High School Students In Administrative Village Of Rawa Buaya In Addressing Pornographic Content On Youtube Social Media. ICCD. https://doi. org/10.33068/iccd.vol1.iss1.31

McRoberts, S., Bonsignore, E., Peyton, T., \& Yarosh, S. (2016). "Do it for the viewers!" Audience engagement behaviors of young YouTubers. In Proceedings of IDC 2016 - The 15th International Conference on Interaction Design and Children. https:// doi.org/10.1145/2930674.2930676

Meek, D. (2012). YouTube and Social Movements: A Phenomenological Analysis of Participation, Events and Cyberplace. Antipode. https://doi.org/10.1111/ j.1467-8330.2011.00942.x

MPBI _ UNESCO. (2013). Kajian Kesiapsiagaan Masyarakat dalam mengantisipasi bencana gempa Bumi dan tsunami di Nias Selatan. Journal of Chemical Information and Modeling. https://doi.org/10.1017/ CBO9781107415324.004

Mulyana, D. (2007). IImu Komunikasi: Suatu Pengantar. Edisi Revisi.

O'Keeffe, G. S., Clarke-Pearson, K., Mulligan, D. A., Altmann, T. R., Brown, A., Christakis, D. A., ... Nelson, K. G. (2011). Clinical report - The impact of social media on children, adolescents, and families. Pediatrics. https://doi.org/10.1542/ peds.2011-0054

Oktari, R. S., Kumala, I. D., Rachmalia, \& Husna, N. (2015). Penguatan Kapasitas Kelembagaan Sekolah dalam Upaya Meningkatkan Ketahanan Masyarakat terhadap Bencana. Simposium Nasional, Mitigasi Bencana Tsunami 2015.

Pemerintah Republik Indonesia. (2007).
Undang-Undang Nomor 24 Tahun 2007 tentang Penanggulangan Bencana. Pemerintah Republik Indonesia.

Pratama, A. (2016). Analisis Faktor Yang Berhubungan Dengan Kesiapsiagaan Dalam Menghadapi Bencana Pada Mahasiswa Sarjana Rumpun IImu Kesehatan Di Universitas Airlangga Surabaya. Perpustakaan Universitas Airlangga.

Pratomo Indyo. (2006). Klasi fi kasi gunung api aktif Indonesia, studi kasus dari beberapa letusan gunung api dalam sejarah. Indonesian Journal on Geoscience.

Ruli As'ari. (2006). Kajian Kesiapsiagaan Masyarakat. In Kajian Kesiapsiagaan Masyarakat Pesisir Dalam Menghadapi Bencana Gempabumi Dan Tsunami Di Kecamatan Cipatujah Kabupaten Tasikmalaya.

Saepulloh. (2020). Imbas Tsunami Banten, Produksi Ikan di Pandeglang Menurun 50 Ribu Ton. Retrieved April 30, 2020, from https://banten.suara. com/read/2020/01/22/162945/imbastsunami-banten-produksi-ikan-dipandeglang-menurun-50-ribu-ton

Sari, R. P., Elanora, D. E., \& Bakar, A. (2017). Perbandingan Efektivitas Penyuluhan Dengan Video Dan Animasi Tentang Makanan Kariogenik Terhadap Pengetahuan Siswa Kelas Iv Di Sdn 027sungai Sapih Kec. Kuranji, Padang. Jurnal B-Dent, 4(No. 2), 117-125. https:// doi.org/10.33854/JBDjbd.103

Sitorus, M. (2009). Peran Komunikasi dan Kontribusi Filantropi dalam Pasca Darurat Bencana. Jurnal IImu Politik Dan Komunikasi.

Sugiyono, P. D. metode penelitian kuantitatif, kualitatif,dan R\&D, Alfabeta, cv. (2016).

Sulaiman, W. (2003). Statistik non-Parametrik: Contoh Kasus dan Pemecahannya dengan SPSS (I). Yogyakarta, Indonesia: Andi.

Tan, L., Ng, S. H., Omar, A., \& Karupaiah, T. (2018). What's on YouTube? A Case Study on Food and Beverage Advertising in Videos Targeted at Children on Social Media. Childhood Obesity. https://doi. org/10.1089/chi.2018.0037

Valency, R. A., \& Lazarte, J. (2007). Towards a Culture of Prevention : Disaster Risk Reduction Begins at School - Good Practices and Lessons Learned. Un/Isdr. 